\title{
Upregulation of the Major Histocompatibility Complex (MHC-I) in Auditory Hair Cells Exposed To Interferon Alpha
}

\author{
Research Article
}

El-Kady MA ${ }^{1,2}$, Li-Korotky HS ${ }^{1,3}$, Durrant JD ${ }^{1}$, Palmer $C^{1,4}$, Sabo $\mathrm{D}^{1,5^{*}}$

${ }^{1}$ Departement of Communication Science and Disorders, School of Health and Rehabilitation Sciences, University of Pittsburgh, USA.

${ }^{2}$ Sohag Faculty of Medicine, Sohag, Egypt.

${ }^{3}$ Basic Research Laboratory, Pediatric Otolaryngology, Children's Hospital of Pittsburgh, University of Pittsburgh Medical Center, USA.

${ }^{4}$ Departement of Audiology, Eye \& Ear Institute, University of Pittsburgh Medical Center, USA.

${ }^{5}$ Departement of Audiology and Speech Pathology, Children's Hospital of Pittsburgh, University of Pittsburgh Medical Center, USA.

\begin{abstract}
Previous studies have reported hearing loss in patients undergoing interferon-alpha (IFN- $\alpha$ ) therapy. The mechanisms by which IFN- $\alpha$ causes hearing loss remain poorly understood. This study was designed to investigate if the immune reaction is one of these mechanisms. Real time-PCR was used to determine the expression of the major histocompatibility class-I (MHC-I) in HEI-OC1 auditory hair cell line. This gene is a marker for an immune response and it is known as H2K1 gene. The cochlear cells were treated by IFN- $\alpha(0,200 \& 2000 \mathrm{U} / \mathrm{ml})$ for $6,12,24 \& 48 \mathrm{Hrs}$. Differential gene expression patterns encoding IFN- $\alpha-1$, IFN- $\gamma$ and H2K1 (MHC-I) were assessed by real-time PCR. The results revealed significant expression of the MHC-I gene in a dose- and time-dependent manner. This outcome indicates that IFN- $\alpha$ led to initiation of an immune reaction in the cochlear cell line. Therefore, the current in-vitro study indicates that the immune reaction might be the underlying mechanism of the hearing impairment observed in patients undergoing IFN- $\alpha$ therapy. These results imply that pre-treatment hearing evaluation and close monitoring of hearing function in patients undergoing long-term high-dose of IFN- $\alpha$ therapy are necessary to avoid or to minimize its adverse effect on hearing.
\end{abstract}

Keywords: Immune Response; Cochlear Cell Line; Major Histocompatibility; Interferon-Alpha.

\begin{abstract}
Abbreviations: IFNs: interferons; IFN- $\alpha$ : interferon-alpha; IFN- $\beta$ : interferon-beta; IFN- $\gamma$ : interferon-gama; rt-PCR: real time polymerase chain reaction;HEI-OC: House Ear Institute- organ of Corti; STATs: signal transducers and activators of transcription; JAK: Janus Kinases; R1: receptor1;R2: receptor2; ISGF-3: interferon-stimulated gene factor-3; ISRE: interferon stimulated response element; GAS: gamma activating sequence; NK: natural killer cells; DCs: dendritic cells; CD: clusters of differerntiation; KLH: keyhole limpet hemocyanin ; ES:endolymphatic sac; FACS: fluoresce-activated cell sorter; SNHL: sensorineural hearing loss; FBS: fetal bovine serum.
\end{abstract}

\section{*Corresponding Author:}

Diane Sabo,

Department of Audiology and Speech-Language Pathology, 4401 Penn Ave, Pittsburgh, PA 15224, USA.

Tel: 412-692-5576

E-mail: Diane.Sabo2@chp.edu

Received: April 18, 2015

Accepted: May 25, 2015

Published: May 26, 2015

Citation: El-Kady MA, Li-Korotky HS, Durrant JD, Palmer C, Sabo D (2015) Upregulation of the Major Histocompatibility Complex (MHC-I) in Auditory Hair Cells Exposed To Interferon Alpha. Int J Clin Exp Otolaryngol. 01(1), 1-9. doi: http://dx.doi.org/10.19070/2572-732X-150001

Copyright: Sabo $\mathbf{D}^{\odot}$ 2015. This is an open-access article distributed under the terms of the Creative Commons Attribution License, which permits unrestricted use, distribution and reproduction in any medium, provided the original author and source are credited.

\section{Introduction}

Interferons (IFNs) are a family of natural proteins secreted in small amounts mainly by the cells of the immune system in response to viral infections, bacterial infections and tumors [47]. Because of its antiviral action, IFN- $\alpha$ is the cornerstone therapy for chronic viral hepatitis, including hepatitis $C$ and hepatitis $B$. Also, because of its effect on the immune response, IFN- $\beta$ is currently the most widely used therapy for multiple sclerosis [41]. As an antiproliferative, IFNs is used in treatment of a number of tumors including hairy cell leukemia [3], chronic myelogenous leukemia, non-Hodgkin lymphoma [27] Kaposi’s Sarcoma [73], renal cell carcinoma [31], melanoma [8] and breast carcinoma [45].

Although IFNs have been successful as potent antivirals, immunomodulators and anticancer agents, treatment with IFN carries significant risks [38]. Many side effects have been reported with IFN therapy, including flu-like symptoms, depression, autoimmune reactions [10], and some blood disorders [66]. In addition, there are a considerable number of studies that have reported 
an association between hearing impairment and IFN therapy, in particular with IFN- $\alpha[20,26,29,43,47,60,65,69,70,84]$. The incidence of hearing impairment due to IFN is reported more frequently in patients with hepatitis $\mathrm{C}$ than in patients receiving IFN for other diseases. The reported cumulative dose that was found to be associated with hearing loss due to IFN- $\alpha$ was around 100 million units $[20,33,46]$.

Different mechanisms have been suggested to explain IFN-induced SNHL, including direct toxic effect on the cochlear cells through apoptosis, inflammatory response, immune response and/or vascular effect that might lead to hemorrhage, ischemia and/or vasculitis of the stria vascularis [20, 26, 29].

The contributions of IFN- $\alpha$ to the immune response involve the activation of the immune system cells as well as the increased secretion of other cytokines that can affect the immune response. For instance, IFN- $\alpha$ induces activation of natural killer cells (NK cells), which are the key cells in the innate immune response [16]. IFN- $\alpha$ also activates T-lymphocytes, in particular, $\mathrm{CD}^{+}$and $\mathrm{CD}^{+}{ }^{+} \mathrm{T}$-cells and enhances their cytotoxicity, and thus promotes the adaptive immune response [88]. Other immune cells stimulated by IFN $-\alpha$ are the dendritic cells (DCs), which are considered professional antigen presenting cells (APCs) [21].

Also, IFN- $\alpha$ is a potent inducer of the major histocompatibility complexes (MHC class I for a greater extent and class II for less extent), the function of which is to hand off processed antigens to phagocytic cells for phagocytosis. Therefore, it is suggested that, IFN- $\alpha$ enhances antigen presentation to T cells [13]. Hence, an increase of the expression of MHC might indicate the immune-modulating effect of IFNs.

In addition, as an immune modulator, IFN- $\alpha$ stimulates the expression of other cytokines, such as IFN- $\gamma$, which ultimately affects the function and activity of many immune cells. IFN- $\gamma$ is also essential for macrophage activation as well as T cell stimulation [14]. In addition, IFN- $\gamma$ itself was found to be expressed in the inner ear as a result of antigin challenge in the endolymphatic sac [63, 64]. Moreover, Gloddek, et al. (2002) [32] found that repeated doses of IFN- $\gamma$ led to significant increase in MHC-II molecules in the cochlear explants of the lateral wall, organ of Corti, modiolus, and spiral ganglia versus the untreated explants. Gloddek et al. (2002) [32] in light of their findings attributed the hearing loss associated with IFNs administration to their robust immunological effects on many cochlear structures.

Furthermore, studies on both animal and human have indicated that IFN- $\gamma$ and IFN- $\alpha$ may upregulate MHC-I molecules on various types of normal cells $[42,49,52]$ and tumor cells $[1,5,7]$. Therefore, through the activation of the cells of the immune system and increasing the secretion of IFN- $\gamma$, IFN- $\alpha$ is capable of initiating a global immune response and function as a key modulator of both innate and adaptive immunity. This means that IFNs can contribute to stimulation of an immune and/or autoimmune response, a sequence that might occur in the inner ear. Therefore, it can be speculated that IFN- $\alpha$ can provoke an immune reaction in the cochlea either directly through activation of cells of the immune system or through production of IFN- $\gamma$.

In summary, the occurrence of hearing loss in patients receiving interferon-alpha $(\mathrm{IFN}-\alpha)$ therapy was reported by many studies; however, the underlying mechanism (s) for this hearing loss has not been delineated. Hence IFN- $\alpha$ contributes largely to the immune system and the immune response contributes to the etiology of a growing number of inner ear disorders; the question that remains is: is the hearing loss, noticed in patients receiving IFN- $\alpha$, due to an immune reaction of the cochlear cells to IFN- $\alpha$ ? Understanding the mechanisms by which IFN- $\alpha$ can cause hearing loss might open an avenue for therapeutic intervention that can protect the inner ear from the ototoxic effect of some medications in general and IFN- $\alpha$ in particular. Hence, the present study was designed to investigate the immune response of the cochlear cells to IFN $-\alpha$ treatment by examining the expression of the MHC-I gene in the HEI-OC1 cell line, using the real time polymerase chain reaction (rt-PCR). In particular, the following research questions were addressed:

1. Can IFN- $\alpha$ gene be expressed in the cochlear cells?

2. Will IFN- $\alpha$ act directly on the cochlear cells or through expression of IFN- $\gamma$ ?

3. Will IFN- $\alpha$ induce an immune response in the cochlear cells through increased expression of the MHC-I encoded by H2K1gene?

To answer the addressed questions, a cochlear hair cell line called HEI-OC (House Ear Institute, Los Angeles, CA) [44, 24, 68, 12$]$ was used as an in-vitro system to examine the molecular events associated with treatment of the organ of Corti cells with IFN- $\alpha$. In particular, the expression of IFN- $\alpha$ gene was examined to ansewer the first question. The expression of IFN- $\gamma$ also was examined to find out if IFN- $\alpha$ acts directly on the cochlear cells or by enhancing the expression of IFN- $\gamma$. To detect if IFN- $\alpha$ can induce an immune response in the cochlear cells, the gene expression for the MHC-I was also examined.

\section{Materials and Methods}

\section{Cell culture}

The HEI-OC1 cell line was cultured on uncoated plastic culture flask, using Dulbecco's modified Eagle medium (DMEM) in the presence of $10 \% \mathrm{CO}_{2}, 50 \mathrm{U} / \mathrm{ml}$ of recombinant IFN- $\gamma$, and $10 \%$ fetal bovine serum under two conditions, permissive conditions and non-permissive conditions. The permissive conditions were in the form of $33^{\circ} \mathrm{C}, 10 \% \mathrm{CO}_{2}$, high-glucose DMEM media, $10 \%$ fetal bovine serum (FBS), and $50 \mu$ IFN- $\gamma$; whereas, the non-permissive conditions included $39^{\circ} \mathrm{C}, 5 \% \mathrm{CO}_{2}$, high-glucose DMEM, and $10 \%$, FBS. When the cells in the culture flask reached around $85 \%$ confluence, they were seeded in the density of $5 \times 10^{4}$ per well containing $2 \mathrm{ml}$ of complete medium, using 4 flat-bottomed 9-well plates, with a total of 36 wells. The 36 wells were divided into four groups according to the number of hours. They were labeled as: $6 \mathrm{hrs}, 12 \mathrm{hrs}, 24 \mathrm{hrs}$, and $48 \mathrm{hrs}$. Each of the four groups was divided into three subgroups-3 wells each (triplicate) according to the dose of IFN- $\alpha$. The first subgroup was labeled as IFN0 acted as a control group, the second subgroup was labeled IFN200, and the third subgroup was labeled IFN2000. Table 1 summerizes the experimental deisgn used in the current study.

\section{Treatment of the cell culture with IFN- $\alpha /$ PBS}

When the cells in the culture plates reached around $85 \%$ confluence, they were treated by IFN- $\alpha$ or PBS corresponding to each subgroup. The IFN0 subgroup was treated with $2000 \mathrm{U} / \mathrm{ml}$ of 
Table 1. Summary of experimental design.

\begin{tabular}{|c|c|c|c|c|c|}
\hline Hours & \multirow{2}{*}{6 hours } & \multirow{2}{*}{12 hours } & \multirow{2}{*}{24 hours } & \multirow{2}{*}{48 hours } & \multirow{2}{*}{ Total \# of wells } \\
\hline Dose & & & & & \\
\hline IFN0 & IFN0/6 & IFN0/12 & IFN0/24 & IFN0/48 & \multirow{2}{*}{12 wells } \\
\hline \# of wells & 3 & 3 & 3 & 3 & \\
\hline IFN200 & IFN2000/6 & IFN200/12 & IFN40/24 & IFN200/48 & \multirow{2}{*}{12 wells } \\
\hline \# of wells & 3 & 3 & 3 & 3 & \\
\hline IFN2000 & IFN2000/6 & IFN2000/12 & IFN2000/24 & IFN2000/48 & \multirow{2}{*}{12 wells } \\
\hline \# of wells & 3 & 3 & 3 & 3 & \\
\hline Total & 9 & 9 & 9 & 9 & 36 wells \\
\hline
\end{tabular}

PBS (control/sham group), the IFN200 subgroup was treated by $200 \mathrm{U} / \mathrm{ml}$ of IFN- $\alpha$, and the IFN2000 subgroup was treated with $2000 \mathrm{U} / \mathrm{ml}$ of IFN- $\alpha$. All the plates were incubated in $39^{\circ} \mathrm{C}, 5 \%$ $\mathrm{CO}_{2}$ for the corresponding period of time, namely $6 \mathrm{hrs}, 12 \mathrm{hrs}$, $24 \mathrm{hrs}$, and $48 \mathrm{hrs}$. After each particular time, the cells were collected from each well and were subjected to cell viability assay.

\section{Cell viability assay}

Cell viability assay was performed to monitor the growth of the culture and to determine the effect of IFN- $\alpha$ on cell growth and cell replications. Cell viability was measured by Trypan blue exclusion. Briefly, $50 \mu \mathrm{L}$ of cell suspension was mixed gently with an equal volume of $0.4 \%$ Trypan blue in a test tube for five minutes at room temperature. Then $10 \mu \mathrm{l}$ of the mixture was placed in a hemocytometer to count the number of viable (unstained) and dead (stained) cells. The average number of unstained cells were calculated in each quadrant of the hemocytometer, and multiplied by $2 \times 10^{5}$ to count the cells $/ \mathrm{ml}$. The cell count was averaged across the three wells (triplicate) for each subgroup. Afterward, the cells were stored in $-80 \mathrm{C}$ for RNA extraction.

\section{RNA extraction}

Cells were homogenized using a TissueLyzer (Qiagen, Valencia, CA). Total RNA was extracted with RNeasy Mini Kit (Qiagen) following manufacturer's instructions. RNA quality and quantity were evaluated by gel electrophoresis on a $1.5 \%$ agarose/TrisBorate-EDTA (TBE) gel using ethidium bromide staining and 260/280 absorbance (ABS) ratio in a Beckman DU 600 Spectrophotometer (Beckman, Fullerton, CA, USA).

\section{Reverse transcription}

Reverse transcription (RT) of RNA was performed to convert the RNA resulting from the previous procedure into recombinant DNA (cDNA), using TaqMan Reverse transcription reagents. The reaction included 10.0 $\mu$ l of 10X PCR TaqMan Gold buffer
II (Applied Biosystems), 30 $\mu \mathrm{l}$ of $25 \mathrm{mM} \mathrm{MgCl}_{2}, 4 \mu \mathrm{l}$ of $25 \mathrm{mM}$ of each dNTP, $5 \mu$ l of $100 \mu \mathrm{M}$ of random primers (Gibco BRL), $2 \mu \mathrm{l}$ of RNasin (40 units; Applied Biosystems), 1.25 $\mu$ l of Super-Script II (250 units; Applied Biosystems) and $5 \mu \mathrm{l}(250 \mathrm{ng})$ of DNA-free total RNA in a final volume of $100 \mu$. The reaction was incubated at $25^{\circ} \mathrm{C}$ for $10 \mathrm{~min}, 50^{\circ} \mathrm{C}$ for $50 \mathrm{~min}$ and $85^{\circ} \mathrm{C}$ for $5 \mathrm{~min}$ in a 2700 Thermocycler (Applied Biosystems Inc., Foster City, CA). The cDNA from this procedure was subjected to rt-PCR to reveal time and dose-dependent changes of the target genes in the hair cell culture challenged by IFN- $\alpha$. In particular rt-PCR was used to measure the magnitude of expression, if any, of some genes that might be stimulated by IFN- $\alpha$, namely IFN- $\alpha 1$, IFN $-\gamma$, and H2K1gene for MHC-I.

\section{Real time Polymerase chain reaction (rt-PCR)}

Gene-specific primers (Table 2) for the target genes (IFN- $\alpha 1$, IFN- $\gamma$, and H2K1gene for MHC-I) were designed using OLIGO Primer Analysis Software (v6.3, Molecular Biology Insights, Inc., Cascade, CO). The reverse transcription reaction was set-up with $250 \mathrm{ng}$ of DNA-free total RNA, random primers and SuperScript III (Invitrogen). The reaction was incubated at $25^{\circ} \mathrm{C}$ for $10 \mathrm{~min}$, $50^{\circ} \mathrm{C}$ for $50 \mathrm{~min}$ and $85^{\circ} \mathrm{C}$ for $5 \mathrm{~min}$ in a 2700 thermocycler (Applied Biosystems Inc., Foster City, CA). The real-time PCR reaction was set-up with SYBR Green PCR reagents (Applied Biosystems), including $5 \mu \mathrm{l}$ of 10X SYBR PCR Buffer, $6 \mu \mathrm{l}$ of $25 \mathrm{mM}$ $\mathrm{MgCl}_{2}, 4 \mu \mathrm{l}$ of each dNTPs (blended with $2.5 \mathrm{mM}$ dATP, dGTP and $\mathrm{dCTP}$, and $5 \mathrm{mM}$ dUTP), $2.5 \mu$ of each gene-specific primer

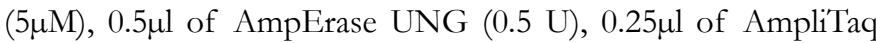
Gold $(1.25 \mathrm{U})$ and $5 \mu \mathrm{l}$ of cDNA in a final volume of $50 \mu \mathrm{l}$. The conditions for the real-time PCR were $50^{\circ} \mathrm{C}$ for $2 \mathrm{~min}, 95^{\circ} \mathrm{C}$ for $12 \mathrm{~min}$, and 40 cycles at $95^{\circ} \mathrm{C}$ for $15 \mathrm{sec}$, and $60^{\circ} \mathrm{C}$ for $1 \mathrm{~min}$ in an ABI PRISM 7900 Sequence Detection system (Applied Biosystems).

7300 Sequence Detection software (Applied Biosystems) was used for instrument control, automated data collection and data analysis. Relative quantification (fold difference) of the expression lev-

Table 2. Primers of the target genes.

\begin{tabular}{|c|c|c|}
\hline Primer & Forward & Reverse \\
\hline IFN- $\alpha 1$ & 5'-CTGATGGTCCTGGCGGTGCT-3' & 5'-CCTTCTCCTGCGGGAATCCAA-3' \\
\hline IFN- $\gamma$ & 5'-AGTCTCTTCT'TGGATATCTG- \\
GAGG-3' & 5'-GTGTGATTCAATGACGCT'TAT- \\
MHC-I & 5'-CAGAG-3' \\
\hline
\end{tabular}


els of each transcript was calculated using the $2^{-\Delta \Delta \mathrm{Ct}}$ method [71] with modifications [51]. The $\Delta \mathrm{Ct}$ represents the $\mathrm{Ct}$ of the target gene normalized to $18 \mathrm{~S} r R N A\left(\Delta \mathrm{Ct}=\mathrm{Ct}_{\text {Target }}-\mathrm{Ct}_{18 \mathrm{~S} \text { rNA }}\right)$. Relative quantification (fold change) of the expression level of the target gene was calculated using a modified $2(\Delta \Delta \mathrm{Ct})$ method, where $\Delta \Delta \mathrm{Ct}=\left(\mathrm{Ct}_{\text {Target }}-\mathrm{Ct}_{18 \mathrm{~S} \text { rRNA }}\right)_{\text {Target }}-\left(\mathrm{Ct}_{\text {Target }}-\mathrm{Ct}_{18 \mathrm{~S} \text { rRNA }}\right)$ Control.

Therefore, the data that collected in the current experiment included the fold change and the $\Delta \mathrm{Ct}$. More than two fold-increase in the gene expression is considered a reliable indication of change in the expression of the gene relative to the control group (sham), which was normalized to the 18S rRNA gene [67].

On the other hand, the $\Delta \mathrm{Ct}$ was collected to quantitatively determine these genes that were expressed in the cochlear cells as a result of IFN- $\alpha$ treatment with respect to dose and time of IFN- $\alpha$ treatment. The $\Delta \mathrm{Ct}$ for each gene was compared across different doses and across different time points. Therefore, there were two independent variables (dose and time) with three and four levels respectively and one dependent variable $(\Delta \mathrm{Ct})$, which created a 3X4 factorial design. (Figure 1).

The first level of the statistical analysis was achieved by calculating the fold-increase for each gene; the gene was considered reliably expressed if there was more than two-fold increase in the PCR products relative to the control group, which was normalized to the $18 \mathrm{~S}$ rRNA. The second level of the analysis was to statistically test for the presence of significant effect of both the dose and the time (two independent variables) on the $\Delta \mathrm{Ct}$ of each gene. Therefore, two-way ANOVA was performed (four levels of time $\mathrm{X}$ three levels of the treatment). In particular, 3 separate two-way ANOVA for each gene was performed. Differences were considered significant if $\mathrm{P}$-value $<0.05$ (i.e. alpha=0.05). ANOVA testing was applied only for those genes that showed more than two-fold increase relative to the control. Afterward, a post hoc analysis, using the least difference test (LSD) was done to examine for significant differences across the three levels of the dose (IFN0, IFN200, and IFN2000); likewise, for significant differences among the four time points (6hrs, $12 \mathrm{hrs}, 24 \mathrm{hrs}$, and 48hrs). LSD does not correct for alpha, which is beneficial for the current study as the least difference would be sufficient to justify significance for these kinds of data.

\section{Results}

\section{Expression of IFN- $\alpha 1$ gene}

Figure 2 shows that there was about $2-4$ folds increase of IFN- $\alpha 1$ gene in the case of $200 \mathrm{U} / \mathrm{ml}$ and about 3.5-6 folds increase in the case of $2000 \mathrm{U} / \mathrm{ml}$. The increase was more during the later hours of treatment, reaching its maximum level at 48 hours in both cases. Table 3 shows the output of the two-way ANOVA, which revealed a significant effect of the dose on the expression of the IFN- $\alpha 1(\mathrm{P}<.05, \mathrm{P}=.000)$. However, the effect of time in hours was not significant $(\mathrm{P}=0.342>0.05)$. The interaction between the dose and the hours was not significant $(\mathrm{P}=0.916)$, which means that the effect of dose was independent of the effect of the time of treatment. Post-hoc analysis reflected significant differences between IFN0 \& IFN200, IFN0 \& IFN2000, and IFN200 \& IFN2000 ( $\mathrm{P}=0.000,0.000, \& 0.004$ respectively).

\section{Expression of IFN- $\gamma$}

The level of the expression IFN- $\gamma$ gene was less than two folds (Figure 3), which indicates that IFN- $\gamma$ gene was not expressed by IFN- $\alpha$ treatment even in small amount at the highest $\mathrm{Ct}$ cycle number used for PCR. Therefore, there was no need to run the two-way ANOVA in this case.

Figure 1. Relative fold changes in IFN- $\alpha 1$ gene expression.

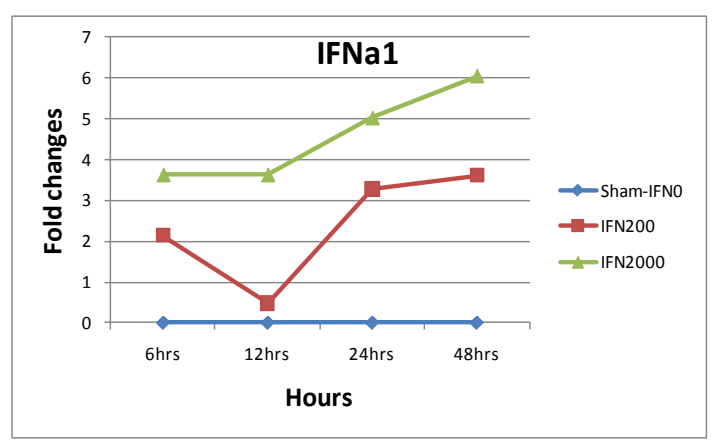

Figure 2: Relative fold changes in IFN- $\gamma$ gene expression

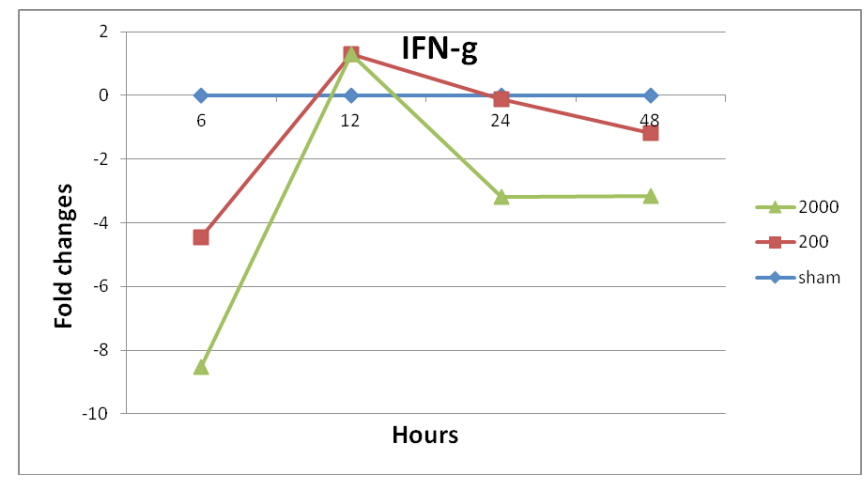


Table 3. Output of two-way ANOVA for $\Delta \mathrm{Ct}$ of IFN- $\alpha 1$ gene.

\begin{tabular}{|c|c|c|c|c|}
\hline Variable & df & Mean Square & F-value & Significance \\
\hline Dose* $^{*}$ & 2 & 50.085 & 69.373 & 0.000 \\
\hline Time & 3 & 0.845 & 1.170 & 0.342 \\
\hline Dose X time & 6 & 0.237 & 0.328 & 0.916 \\
\hline
\end{tabular}

*: The mean difference is significant at the 0.05 level

Figure 3. Relative fold changes of MHC-I gene expression.

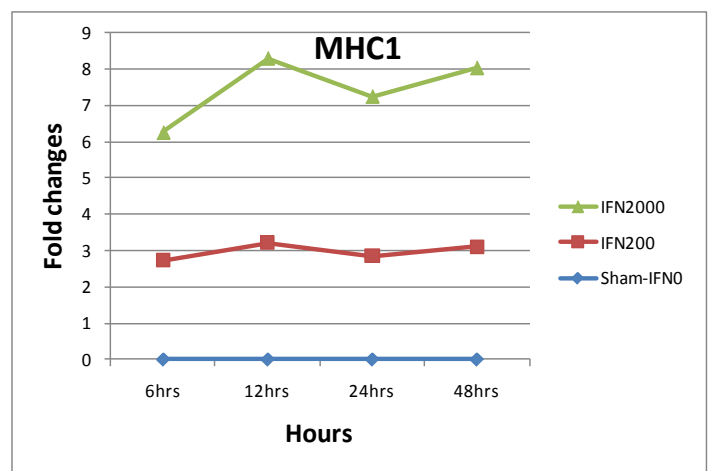

\section{Expression of the MHC-I gene}

The result showed an increase in the MHC1 gene expression by about 3 folds in case of $200 \mathrm{U}$ of IFN- $\alpha$ versus $6-8$ fold-increases in case of $2000 \mathrm{U}$ of IFN- $\alpha$. It is noticed that the pattern of the fold change was similar for both cases (Table 4).

In addition, the two-way ANOVA indicated significant effects for both dose and time on the $\Delta$ Ct of MHC-I gene, with $\mathrm{P}=0.000$ and 0.001 respectively (Table 5). The results of LSD test indicated significant differences between IFN0 \& IFN200, IFN0 \& IFN2000, and IFN200 \& IFN2000 (P=0.000, 0.000, and 0.000 respectively) (Table 6). On the other hand, Table 7 shows the output of LSD test that indicated significant differences between 6 \& 24 hrs, $12 \& 24$ hrs, $24 \& 48$ hrs time points $(\mathrm{P}=0.001,0.029$, and 0.000 respectively).

Table 4. Post-hoc analysis for the effect of dose on $\Delta \mathrm{Ct}$ for IFN- $\alpha 1$ gene.

\begin{tabular}{|c|c|c|}
\hline Levels of dose & Std Error & Significance \\
\hline IFN0-IFN200* & 0.34688 & 0.000 \\
\hline IFN0-IFN2000* & 0.34688 & 0.000 \\
\hline IFN200-IFN2000* & 0.34688 & 0.004 \\
\hline
\end{tabular}

*: The mean difference is significant at the 0.05 level

Table 5. Output of two-way ANOVA for $\Delta \mathrm{Ct}$ of MHC-I gene.

\begin{tabular}{|c|c|c|c|c|}
\hline Variable & df & Mean Square & F-value & Significance \\
\hline Dose* & 2 & 15.618 & 246.631 & 0.000 \\
\hline Time* $^{*}$ & 3 & 0.464 & 7.320 & 0.001 \\
\hline Dose X hours & 6 & 0.102 & 1.604 & 0.189 \\
\hline
\end{tabular}

*: The mean difference is significant at the 0.05 level

Table 6. Post-hoc analysis for the effect of dose on $\Delta \mathrm{Ct}$ of MHC-II gene.

\begin{tabular}{|c|c|c|}
\hline Levels of dose & Std Error & Significance \\
\hline FN0-IFN200* & 0.10273 & 0.000 \\
\hline IFN0-IFN2000* & 0.10273 & 0.000 \\
\hline IFN200-IFN2000* & 0.10273 & 0.000 \\
\hline
\end{tabular}

*: The mean difference is significant at the 0.05 level 
Table 7. Post-hoc analysis for the effect of time on $\Delta \mathrm{Ct}$ of MHC-I gene.

\begin{tabular}{|c|c|c|}
\hline Levels of time & Std Error & Significance \\
\hline 6-12 hrs & 0.11863 & 0.116 \\
\hline 6-24 hrs* & 0.11863 & 0.001 \\
\hline 6-48 hrs & 0.11863 & 0.868 \\
\hline 12-24 hrs* & 0.11863 & 0.029 \\
\hline 12-48 hrs & 0.11863 & 0.085 \\
\hline $24-48$ hrs* & 0.11863 & 0.000 \\
\hline
\end{tabular}

\section{Discussion}

The first research question asked if IFN- $\alpha$ can be expressed in the cochlear cells. One subtype of IFN- $\alpha$ was tested to answer this question, i.e. the IFN- $\alpha 1$ gene. The results showed more than two fold-increases in the expression of the IFN- $\alpha 1$ gene (Figure 2). This increase was more apparent in case of the IFN2000 group than in the IFN200 group. These findings suggest that the dose of IFN- $\alpha$ affects the level of expression of IFN- $\alpha 1$. Therefore, it can be concluded that IFN- $\alpha$ gene can be expressed in the cochlear cells with subsequent expression of other IFN- $\alpha$-induced genes, such as MHC-I as an immune response gene.

Although IFN- $\alpha$ is well known to induce IFN- $\gamma[16,61]$ and IFN- $\gamma$ was found to be expressed in the inner ear $[32,33]$ the results of the current study revealed less than two fold-increases in the IFN- $\gamma$ gene expression (Figure 3). This means that the growing cells from the cochlear cell line used in the current experiment did not produce IFN- $\gamma$. Many studies have shown that IFN- $\gamma$ can be produced in the inner ear as a result of antigen challenge [32, 63] and in association with autoimmune $\mathrm{SNH}$ human subjects $[53,72]$. Moreover, the expression of IFN- $\gamma$ in the inner ear in these studies was associated with the expression of inflammatory markers called the intercellular adhesion molecules-1 (ICAM1) $[63,75]$ and immune response marker (MHC-II) [32]. This means that IFN- $\gamma$ was associated with induction of inflammatory and immune responses in the inner ear. These findings provide evidence for the production of IFN- $\gamma$ in the inner ear in association with inner ear injury or pathology, which is not the case in the current study. The events in the current study were not based on ongoing antigen challenges or stimulation of the immune system cells (the cochlear cell line used in the current study was not exposed to any kind of antigen or cell injury), rather they reflected molecular or genetic signaling events and this may explain the difference in findings.

At the molecular level, the results of the current study might be in agreement with the study of Nguyen, et al. (2000) [58] who found that IFN- $\alpha$ and IFN- $\beta$ did not enhance the expression of IFN- $\gamma$. They attributed this to a negative regulation between type I-IFN (IFN- $\alpha$ \& IFN- $\beta$ ) and type II-IFN to STAT1, which is involved in the signaling pathway of both types of IFN [25, 57]. When these two cytokines had an alternative signaling pathway that did not involve STAT1, they promoted the expression of IFN- $\gamma$ [58]. Therefore, it can be argued that IFN- $\alpha$ used the Jak-STAT signaling pathway with activation of STAT1 in the cochlear cell culture, and hence, it was not able to promote the expression of IFN- $\gamma$. This pathway needs to be tested in order to elucidate this issue. Therefore, it can be concluded that treatment of cochlear cell line with IFN- $\alpha$ did not induce expression of the IFN- $\gamma$ gene, which suggests that IFN- $\gamma$ did not mediate the action of IFN- $\alpha$; instead,
IFN- $\alpha$ might have acted directly on the cochlear cells.

On the other hand, the results showed more than two-fold increases in the expression of the MHC-I gene in the cochlear cells treated by IFN- $\alpha$. The expression was relatively high in both doses of IFN- $\alpha$ and over all time points, which might suggest that MHC-I was expressed constantly in the treated cochlear cell culture. The function of the MHC-I molecules is to present processed antigen to cytotoxic T cells and bind to CD4 (co-stimulatory molecules) on the surface of T-cells. It is well-known that IFN- $\alpha$ induces activation of $\mathrm{CD}^{+}{ }^{+} \mathrm{T}$-cells and thus promotes their cytotoxicity, with subsequent expression of the MHC-I molecules [88]. In addition, IFN- $\alpha$ stimulates the DCs, which are considered professional APCs [21]. Therefore, IFN $-\alpha$ can enhance antigen presentation to T-cells with a subsequent expression of MHC-I [13]. Further procedures are needed to examine the existence of these cells in the growing HEI-OC1.

At the molecular level, the promoter (i.e., a part of the gene with which a stimulating molecule will attach to induce expression of that gene) of the MHC-I genes contains an interferon response sequence (IRS), which leads to expression of MHC-I once IFN- $\alpha$ is introduced [78]. Therefore, treatment of the cochlear cell culture with IFN- $\alpha$ most probably led to expression of MHC-I gene.

The results of the current study may be in agreement with what has been documented by many studies that MHC-I is a "hallmark" of type I-IFN, including IFN- $\alpha$ [17]. In addition, IFN- $\alpha$ treatment is important for colonel expansion and survival of the $\mathrm{CD}^{+}$and $\mathrm{CD}^{+}{ }^{+}$T-cell populations (MHC-I bind to the surface of these cells) in an antigen-independent manner, a mechanism called "bystander effect" $[62,81]$. Although this bystander effect is not as powerful as a response during viral infection, it still represents a unique mechanism of controlling an adaptive immune response [81]. Moreover, IFN- $\alpha$ causes an alteration of the MHC with increased expression of class I molecules on the tumor cells [59]. All these findings support the notion that IFN- $\alpha$ is a potent inducer of MHC-I even in the absence of antigen challenge.

Notably, lymphocytes (which are the cells of the adaptive immune response) are not normally present in the cochlea; however, the cochlear innate immunity is suggested to be responsible for initiating the adaptive immune response with subsequent recruitment of lymphocytes. Therefore treatment with IFN- $\alpha$, which is well known by its priming action (initiates the innate immune response) and its bystander effect (needs no antigen) will promote the development of adaptive immune response with subsequent lymphocytic activation, leading to MHC-I production in the cochlear cell culture regardless of the absence of antigen exposure. This conclusion might explain the constant expression of MHC-I over all the time points and in both doses $(200 \& 2000 \mathrm{U} / \mathrm{ml})$. 
Many studies have shown the involvement of lymphocytes, including $\mathrm{CD}^{+} \& \mathrm{CD} 8^{+}$T-cells (cells of adaptive immunity) as well as NK cells (cells of innate immunity) with the production of IFN- $\gamma$ and ICAM1 in the pathogenesis of immune-mediated inner ear disorders in human subjects as well as in experimental animals $[6,32,53,56,87]$. This association between hearing loss and the immune response suggests that IFN- $\alpha$ can cause hearing impairment by promoting the innate as well as the adaptive immune responses in the cochlea. This speculation is supported by the studies of Cadoni et al. $(2001 ; 2003)[18,19]$. These investigators found anti-endothelial cell antibodies in 15 out of $32(47 \%)$ patients who had sudden hearing loss due to IFN- $\alpha$ versus two out of 14 of the controls (14\%). This suggested an association between sudden hearing loss and immune-mediated microvascular damage. These anti-endothelial cell antibodies react against surface antigens on the endothelial cells of the inner ear blood vessels, leading to their damage via a complement-mediated or antibody-dependent cellular cytotoxic mechanism. The same effect has been detected in retinal vascular lesions during interferon therapy [34]. Interferon therapy can provoke an immune response in the inner ear, resulting in hearing impairment.

Overall, the effects of IFN- $\alpha$ on the expression of MHC-I gene were dose and time dependent. Also, the pattern of changes in the gene expression across hours look to be identical for both doses $(200 \& 2000 \mathrm{U} / \mathrm{ml})$. These findings may be consistent with the dose-dependent response typically seen with cytokines treatment. For instance, low-dose treatment has a stimulating effect, whereas, high-dose produces tolerating or suppressant energies $[15,37,77]$. This observation did not point to an absolute stimulation or an absolute depression; rather it meant that low and high doses have distinctive outcomes. For example, Yoshino (1996) [89] found that a low dose of IFN- $\alpha$ caused downregulation of delayed hypersensitivity and cellular infiltration in lymph nodes. On the other hand, high doses were found to be clinically effective against neoplasm and against viral infection, but they are poorly tolerated by the patients [82]. Systemic administration of low doses of IFN- $\alpha$ during anti-neolplastic or antiviral therapy will act as a priming cytokines for the host immune system, resulting in protection from viral challenge and increase of the tolerance of the patient to the effect of $\operatorname{IFN}-\alpha[9,28]$. Theoretically, low-doses of IFN- $\alpha$ mimic the early endogenous priming effect by innate immunity versus high-dose treatment that resembles the systemic adaptive immune response, which is usually vigorous and more generalized [80]. The innate and the adaptive immunity have distinctive cytokines production and distinctive cellular activation, which might make the outcome of low-dose treatment distinctive from the high-dose treatment.

This assumption would provide an explanation for some clinical findings associated with IFN- $\alpha$ treatment. For example, Kanemaru et al. (1997) [48] used IFN- $\alpha$ to treat patients with severe idiopathic SNHL due to viral infection. A significant number of those patients showed complete recovery after IFN- $\alpha$ therapy of a total cumulative dose of 30 million units. The recovery of the hearing loss in their study was most probably due, first, to enhancement of the antiviral effect that in turn overcame the viral assault in the inner ear. This antiviral effect was indicated by the concomitant increase in 2, 5 oligoadenylate synthetase (2,5 A-S) activity. Second, the recovery of the hearing loss might be attributed to a different pathway of IFN- $\alpha$ in the inner ear when it is used in low doses through the priming effect. This different pathway might have led to induction of other genes such as anti- inflammatory or anti-apoptotic genes with subsequent recovery of the hearing loss.

Furthermore, the results of the current study may be consistent with a considerable number of studies that found an association between SNHL and high doses of IFN- $\alpha$ therapy, especially in patients with hepatitis $C[26,65,84,29,60,20,47]$. The authors of these studies attributed this hearing loss to the inflammatory response or the immune response of IFN- $\alpha$ on the hair cells that might have led to apoptosis. The reported cumulative dose that was found to be associated with the occurrence of SNHL was more than 100 million units (i.e., about three times the cumulative dose used in the treatment of SNHL in the study of Kanemaru et al. (1997) [48]. Therefore, it can be concluded that IFN- $\alpha$, when used in small doses, can produce different effects on the cochlear cells from when it was used in large doses. This suggests that IFN $-\alpha$ has dual actions; protective in small doses and harmful in large doses.

\section{Conclusion}

IFN $\alpha 1$ gene can be expressed in the cochlear cells as a result of IFN- $\alpha$ treatment with subsequent expression of MHC-I gene, which is a an immune response gene. This immune response was mediated by IFN- $\alpha$, not through IFN- $\gamma$. The administration schedule of IFN- $\alpha$ treatment may play an important role on its biological and therapeutic effects by shaping the innate and the adaptive immune responses. In particular, low-dose of IFN- $\alpha$ can be used to protect against viral infection or immune-mediated disorders. On the other hand careful observation and follow ups might be necessary in case of long-term, high-dose therapy of IFN $\alpha$; two measures that can be applied to protect against hearing impairment.

\section{Directions for Future Research}

- A wide range of doses that extended from 10 to 100,000U/ $\mathrm{ml}$ can be used. This will help in determining different biological characteristics of IFN- $\alpha$ that are largely dependent on dose. Also, repeated doses might be helpful to mimic the actual therapeutic course of IFN- $\alpha$ and to help in magnifying an immune response.

- Other markers for immune responses such as markers for $\mathrm{CD}^{+}, \mathrm{CD}^{+}$and NK cells might be helpful in understanding the mechanisms involved in IFN- $\alpha$-induced hearing loss.

- Immunohistochemical studies might be helpful in determining the functional effect of these genes that are affected by IFN- $\alpha$ treatment by detecting their corresponding proteins.

- Animal models can be used to mimic the biological events that can occur in vivo as a result of IFN- $\alpha$ treatment.

- Prospective studies that include subjects receiving IFN- $\alpha$ therapy for different diseases (such as hepatitis $\mathrm{C}$, hepatitis $\mathrm{B}$, malignancies.etc) need to be conducted. These patients should have their hearing tested before starting the therapy and every three or six months during the therapy. The hearing evaluation should include basic audiological testing as well as otoacoustic emissions to detect early changes that might occur in the cochlea.

\section{Acknowledgement}

Funding support was from NIDCD-DC007511 (H.-S. Li-Korot- 
ky) and the School of Health \& Rehabilitation Science (SHRS). Technical assistance was from Allison Doyle, Cathy Lo, and Julie Banks from Basic Research Laboratory, Pediatric Otolaryngology, Children's Hospital of Pittsburgh.

\section{References}

[1]. Abril E, Mendez RE, García A, Serrano A, Cabrera T, et al. (1996) Characterization of a gastric tumor cell line defective in $\mathrm{MHC}$ class I inducibility by both alpha- and gamma-interferon. Tissue Antigens 47(5): 391-398.

[2]. Aguet M, Grobke M, Dreiding, P (1984) Various human interferon subclasses crossreact with common receptors, their binding affinities correlate with their specific biological activities. Virology 132(1): 211- 216

[3]. Ahmed S, Rai K.R (2003) Interferon in the treatment of hairy-cell leukemia. Best Practice and Research Clinical Haematology 16(1): 69-81.

[4]. Altermatt H.J, Gebbers J.O, Muller C, Arnold W, Laissue J.A (1990) Human endolymphatic sac, Evidence for a role in inner ear immune defense. ORL Journal of Otorhinolaryngology and Related Specialities 52(3): 143-148.

[5]. Anderson RC, Elder JB, Brown MD, Mandigo CE, Parsa AT, et al. (2002) Changes in the immunologic phenotype of human malignant glioma cells after passaging in vitro. Clin Immunol 102(1): 84-95.

[6]. Arnold W, Pfaltz R, Altermatt H-J, (1987) Evidence of serum antibodies against inner ear tissues in the blood of patients with certain sensorineural hearing disorders. Acta Otolaryngologica (Stockh) 99(3-4): 437-444.

[7]. Atta MS, Irving WL, Powell RJ, Todd I (1995) Enhanced expression of MHC class I molecules on cultured human thyroid follicular cells infected with reovirus through induction of type 1 interferons. Clin Expl Immunol 101(1): 121-126.

[8]. Balch CM, Soong SJ, Gershenwald JE, Thompson JF, Reintgen DS, et al. (2001) Prognostic factors analysis of 17,600 melanoma patients, validation of the American Joint Committee on Cancer melanoma staging system. Journal of Clinical Oncology 19(16): 3622-3634.

[9]. Beilharz M.W, McDonald W, Watson M.W, Heng J, McGeachie J, et al. (1997) Low-dose oral type I interferons reduce early virus replication of murine cytomegalovirus in vivo. Journal of Interferon Cytokine Research 17(10): 625-30

[10]. Benelhadj S, Marcellin P, Castelnau C, Colas-Linhart N, Benhamou JP, et al. (1997) Incidence of dysthyroidism during interferon therapy in chronic hepatitis C. Hormonal Research 48(5): 209-14.

[11]. Berrocal J.R G, Ramirez-Camacho R ( 2000) Immune response and immunopathology of the inner ear, an update. Journal of Laryngology and Otology 114(2): 101-7.

[12]. Bertolaso L, Martini A, Bindini D, Lanzoni I, Parmeggiani A, et al. (2001) Apoptosis in the OC-k3 immortalized cell line treated with different agents. Audiology 40(6): 327-335.

[13]. Biron C. A (1998) Role of early cytokines, including and interferons (IFN/ ), in innate and adaptive immune responses to viral infections. Seminars in Immunology 10(5): 383-390.

[14]. Biron C. A (1999) Initial and innate responses to viral infections-pattern setting in immunity or disease Current Opinion in Microbiology 2(4): 374381

[15]. Biron C. A (2001) Interferons alpha and beta as immune regulators-a new look Immunity 14(6): 661-664.

[16]. Biron C. A, Nguyen K. B, Pien G. C, Cousens L.P, Salazar-Mather T. P (1999) Natural killer cells in antiviral defense, function and regulation by innate cytokines. Annual Review of Immunology 17(1): 189-220.

[17]. Brucet M, Marqués L, Sebastián C, Lloberas J, Celada A (2004) Regulation of murine Tap1 and Lmp2 genes in macrophages by interferon gamma is mediated by STAT1 and IRF-1. Genes and Immunity 5(1): 26-35.

[18]. Cadoni G, Agostino S, Manna R, De Santis A, Fetoni A.R, et al. (2003) Clinical associations of serum antiendothelial cell antibodies in patients with sudden sensorineural hearing loss. Laryngoscope 113(5): 797-801.

[19]. Cadoni G, Fetoni A. R, Agostino S, De Santis A, Vulpiani P, et al. (2001) Role of endothelial cell autoantibodies in the pathogenesis of sudden hearing loss. Acta Otorhinolaryngology 21(3): 138-43.

[20]. Cadoni G, Marinelli L, De Santis A, Romito A, Manna R, et al. (1998) Sudden hearing loss in a patient hepatitis $\mathrm{C}$ virus (HCV) positive on therapy with alpha-interferon, a possible autoimmune-microvascular pathogenesis. Journal of Laryngology and Otology 112(10): 962-963.

[21]. Cella M, F. Facchetti, A. Lanzavecchia, M. Colonna (2000) Plasmacytoid dendritic cells activated by influenza virus and CD40L drive a potent TH1 polarization. Nature Immunology 1(4): 305-10.

[22]. Chatterjee-Kishore M, Kishore R, Hicklin D.J, Marincola F.M, Ferrone S (1998) Different requirements for signal transducer and activator of transcription 1alpha and interferon regulatory factor 1 in the regulation of low molecular mass polypeptide 2 and transporter associated with antigen pro- cessing 1 gene expression. Journal of Biological Chemistry 273 (26): 16177 83

[23]. Colonna M, Krug A, Cella M (2002) Interferon-producing cells, on the front line in immune responses against pathogens. Current Opinion in Immunology 14(3): 373.

[24]. Devarajan P, Savoca M, Castaneda M.P, Park M.S, Esteban-Cruciani N, et al. (2002) Cisplatin-induced apoptosis in auditory cells, role of death receptor and mitochondrial pathways. Hearing Research 174(1-2): 45-54.

[25]. Durbin J. E, Hackenmiller R., Simon M.C, Levy D. E (1996) Targeted disruption of the mouse Stat 1 gene results in compromised innate immunity to viral disease. Cell 84(3): 443-450.

[26]. Elloumi H, Houissa F, Hadj NB, Gargouri D, Romani M, et al. (2007) Sudden hearing loss associated with peginterferon and ribavirin combination therapy during hepatitis $\mathrm{C}$ treatment. World Journal of Gastroenterology 13(40): 5411-5412.

[27]. Ezaki K (1996) Cytokine therapy for hematological malignancies. International Journal of Hematology 65(1): 17-29(13).

[28]. Ferbas J.J, Toso J.F, Logar A.J, Navratil J.S, Rinaldo C.R, (1994) CD4+ blood dendritic cells are potent producers of IFN-alpha in response to in vitro HIV-1 infection. Journal of Immunology 152(9): 4649-4662.

[29]. Formann E, Stauber R, Denk D.M, Jessner W, Zollner G, et al. (1994) Sudden hearing loss in patients with chronic hepatitis $\mathrm{C}$ treated with pegylated interferon/ribavirin. Annals Journal of Gastroenterololgy 99(5): 873-7.

[30]. Fuse T, Hayashi T, Ota N, Fukase S, Asano S, et al. (2003) Immunological responses in acute low-tone sensorineural hearing loss and Ménière's disease. Acta Otolaryngology 123(1): 26-31.

[31]. Gleave M.E, Elhilali M, Fradet Y, Davis I, Venner P, et al. (1998) Interferon gamma-1b compared with placebo in metastatic renal-cell carcinoma. $\mathrm{Ca}-$ nadian Urologic Oncology Group. The New England Journal of Medicine 338(18): 1265-1271.

[32]. Gloddek B, Bodmer D, Brors D, Keithley E. M, Ryan A. F (2002) Induction of MHC Class II Antigens on Cells of the Inner Ear. Audiology and Neurootology 7(6): 317-23

[33]. Gorur K, Kandemir O, Unal M, Özcan C (2003) The effect of recombinant interferon alpha treatment on hearing thresholds in patients with chronic hepatitis B. Auris Nasus Larynx 30(1): 41-44.

[34]. Guyer D.R, Tiedeman J, Yannuzzi L.A, Slakter J.S, Parke D, et al. (1993) Interferon-associated retinopathy. Archives of Ophthalmology 111(3): 3506.

[35]. Haque SJ, Williams BR (1994) Identification and characterization of an interferon (IFN)-stimulated response element-IFN-stimulated gene factor 3-independent signaling pathway for IFN-alpha. J Biol Chem 269(30): 19523-9.

[36]. Harris J.P, Sharp P.A (1990) Inner ear autoantibodies in patients with rapidly progressive sensorineural hearing loss. Laryngoscope 100(5): 516-24.

[37]. Havell E. A, Spitalny G. L (1983) Endotoxin-induced interferon synthesis in macrophage cultures. Journal of Reticuloendothelial Society 33(5): 369380 .

[38]. Heathcote J, Main J, (2005) Treatment of hepatitis C. Journal of Viral Hepatitis 12(3): 223-235.

[39]. Ihle J.N, Witthuhn B, Tang B, Yi T, Quelle F.W, (1994) Cytokine receptor and signal transduction. Baillieres Clinical Haematology 7(1): 17-48.

[40]. Isaacs, Lindenmann (1957) Virus Interference. I. The interferon". Proceedings of Royal Society of London Biological Science 147(927): 258-267.

[41]. Jacobs L.D, Cookfair D.L, Rudick R.A, Herndon R.M, Richert J.R, et al (1996) Intramuscular interferon beta-1a for disease progression in relapsing multiple sclerosis. The Multiple Sclerosis Collaborative Research Group (MSCRG). Annals of Neurology 39 (3): 285-94

[42]. Jarosinski K.W, Massa P.T (2002) Interferon regulatory factor-1 is required for interferon-gamma-induced MHC class I genes in astrocytes. J. Neuroimmunol 122(1-2): 74-84.

[43]. Johnson K, Sargent L.A, Galizio C, Ubogu E.E ( 2008) Interferon-alpha-2b/ ribavirin-induced vestibulocochlear toxicity with dysautonomia in a chronic hepatitis C patient. European Journal of Gastroenterology and Hepatology 20(11): 1110-1114

[44]. Kalinec G.M, Webster P, Lim D. J, Kalinec F ( 2003) A Cochlear Cell Line as an in vitro System for Drug Ototoxicity Screening. Audiology \& Neurootology 8(4): 177-189.

[45]. Kamamura Y, Takahashi K, Komaki K, Monden Y (1998) Effects of interferon-alpha and gamma on development of LAK activity from mononuclear cells in breast cancer patients. Journal of Medical Investigation 45(1-4): 715 .

[46]. Kanda Y, Shigeno K, Matsuo H, Yano M, Yamada N, et al. (1995) Interferon-induced sudden hearing loss. Audiology 34(2): 98-102.

[47]. Kanda Y, Shigeno K, Kinoshita N, Nakao K, Yano M, et al. (1994) Sudden hearing loss associated with interferon. Lancet 343(8906): 1134-1135.

[48]. Kanemaru S, Fukushima, H, Nakamura H, Tamaki H, Fukuyama Y, et al. (1997) Alpha-Interferon for the treatment of idiopathic sudden sensorineu- 
ral hearing loss. European Archives of Otorhinolaryngology 254(3): 158-62.

[49]. Keir ME, Stoddart CA, Linquist-Stepps V, Moreno ME, McCune JM ( 2002) IFN-alpha secretion by type 2 predendritic cells upregulates MHC class I in the HIV-1-infected thymus. J. Immunol 168(1): 325-331.

[50]. Leonard W.J, O'Shea J.J (1998) Jaks and STATs: biological implications. Ann. Rev. Immunol 16: 293-322.

[51]. Li-Korotky H.S, Lo C.Y, Zeng F.R, Lo D, Banks J.M ( 2009) Interaction of phase variation, host and pressure/gas composition: Pneumococcal gene expression of PsaA, SpxB, Ply, and LytA in simulated middle ear environments. Intern. J. Ped. Otorhinolaryngol 73(10): 1417-1422.

[52]. Ljunggren G, Anderson D.J (1998) Cytokine induced modulation of MHC class I and class II molecules on human cervical epithelial cells. J. Reprod Immunol 38(2): 123-138.

[53]. Lorenz R.R, Solares C.A, Williams P, Sikora J, Pelfrey C.M, et al. (2002) Interferon-gamma production to inner ear antigens by $\mathrm{T}$ cells from patients with autoimmune sensorineural hearing loss. J. Neuroimmunol 130(1-2): 173-178.

[54]. Mayot D. Bene M.C, Dron K, Perrin C, Faure G.C (1993) Immunologic alterations in patients with sensorineural hearing disorders. Clin. Immunol Immunopathol 68 (1): 41-45.

[55]. McCabe B.F (1979) Autoimmune sensorineural hearing loss. Ann Otol. Rhinol. Laryngol 88(5): 585-589.

[56]. McCabe B.F, McCormick K.J (1984) Tests for autoimmune disease in otology. The Am J Otol 5(6): 447-9.

[57]. Meraz MA, White JM, Sheehan KC, Bach EA, Rodig SJ, et al. (1996) Targeted disruption of the Stat 1 gene in mice reveals unexpected physiologic specificity in the JAK-STAT signaling pathway. Cell 84(3): 431-442.

[58]. Nguyen K.B, Cousens L.P, Doughty L.A, Pien G.C, Durbin J.E, et al. (2000) Interferon alpha/beta-mediated inhibition and promotion of interferon gamma: STAT1 resolves a paradox. Nat. Immunol 1(1): 70-6.

[59]. Oberg K (1992) The action of interferon alpha on human carcinoid tumours. Seminars in Cancer Biol 3(1): 35-41.

[60]. Okanoue T, Sakamoto S, Itoh Y, Masahito, Yasui Y, et al. (1996) Side effects of high-dose interferon therapy for chronic hepatitis C. J. Hepatol. 25(3): 283-291.

[61]. Orange J.S, Biron C.A (1996) Characterization of early IL-12, IFN-alphabeta, and TNF effects on antiviral state and NK cell responses during murine cytomegalovirus infection. J Immunol 156(12): 4746-56.

[62]. Parronchi P, Mohapatra S, Sampognaro S, Giannarini L, Wahn U, et al. (1996) Effects of interferon-alpha on cytokine profile, T cell receptor repertoire and peptide reactivity of human allergen-specific $\mathrm{T}$ cells. Eur J. Immunol 26(3): 697-703.

[63]. Pawankar R, Tomiyama S, Ikezono T, Nonaka M, Jinnouchi K, et al. (2004) Interferon-g expression in the inner ear of rats following secondary immune reaction in the endolymphatic sac. Acta Otolaryngol. Suppl 553: 6-12.

[64]. Pawankar R, Tomiyama S, Jinnouchi K, Ikezono T, Nonaka M, et al. (1998) Intercellular adhesion molecule- 1 expression in the inner ear of rats following secondary immune reaction in the endolymphatic sac. Acta Otolaryngologica (Stockh), Supplement 118(539): 5-14.

[65]. Piekarska A, Jozefowicz-Korczynska M, Wojcik K, Berkan E ( 2007) Sudden hearing loss in chronic hepatitis $C$ patient suffering from Turner syndrome, treated with pegylated interferon and ribavirin. Intern. J. Audiol 46(7) : 34550.

[66]. Poynard T, Bedossa P, Chevallier M, Mathurin P, Lemonnier C, et al. (1995) A comparison of three interferon alfa- $2 b$ regimens for the long term treatment of chronic non-A, non-B hepatitis. New England Journal of Medicine 332(22): 1457-62.

[67]. Proudnikov D, Yuferov V, Zhou Y, LaForge K.S, Ho A, et al. (2003) Optimizing primer--probe design for fluorescent PCR. J. Neurosci. Meth 123(1): $31-45$.

[68]. Rivolta M.N, Holley M.C (2002) Asymmetric segregation of mitochondria and mortalin correlates with the multi-lineage potential of inner ear sensory cell progenitors in vitro. Developmental Brain Research 133(1): 49-56.

[69]. Sachar S, Polio J (2004) Pegylated-interferon-induced ototoxicity as a side effect of hepatitis C treatment. American Journal of Gastroenterology 99(10): Suppl. S96.

[70]. Salkic N, Zerem E, Zildzic M, Basic M (2009) Reversible peg-interferoninduced unilateral sensorineural hearing loss during hepatitis B treatment. The Turkish Journal of Gastroenterology 20(2): 156.

[71]. Schmittgen T.D, Zakrajsek B.A (2002) Effect of experimental treatment on housekeeping gene expression: validation by real-time, quantitative RTPCR. Journal of Biochemical Biophysical Methods 46(1-2): 69-81.

[72]. Solares C.A, Tuohy V.K (2005) ELISPOT determination of interferon-gamma T-cell frequencies in patients with autoimmune sensorineural hearing loss. Methods of Molecular Biology 302: 253-260.

[73]. Stadler R (1998) Interferons in dermatology. Present-day standard. Dermatology Clinical 16 (2): 377-98.

[74]. Suzuki M, Krug M, Cheng K-C (1997) Antibodies against inner-ear proteins in the sera of patients with inner-ear diseases. ORL. Journal for Otorhindaryngol Related Specialities 59(1):10-17.

[75]. Suzuki M, Harris J.P (1995) Expression of intercellular adhesion molecule-1 during inner ear inflammation. The Ann. Otol. Rhinol Laryngol 104(1): $69-75$.

[76]. Takahashi M, Harris J.P (1988) Analysis of immunocompetent cells following inner ear immunostimulation. Laryngoscope 98: 1133-1138.

[77]. Taylor J. L, Grossberg S. E, (1998) The effects of interferon-alpha on the production and action of other cytokines Seminars in Oncology 25(suppl 1): 23-29.

[78]. Ten R.M, Blank V, Le, Bail O, Kourilsky P, et al. (1993) Two factors, IRF1 and KBF1/NF-kappa B, cooperate during induction of MHC class I gene expression by interferon alpha beta Newcastle disease virus. C R Acad Sci III 316(5): 496-501.

[79]. Tomiyama S,Harris J.P (1987) The role of the endolymphatic sac in inner ear immunity. Acta Otolaryngol 103(3-4): 182-8.

[80]. Tompkins W. A (1999) Immunomodulation and therapeutic effects of the oral use of interferon-alpha: mechanism of action. Journal of Interferon and Cytokine Research 19(8): 817-828.

[81]. Tough D. F, Borrow P, Sprent J (1996) Induction of bystander T cell proliferation by viruses and type I interferon in vivo Science 272(5270): 1947-50.

[82]. Tovey M. G, Meritet J. P, Guymarho J, Maury C (1999) Mucosal cytokine therapy: marked antiviral and antitumor activity. Journal of Interferon and Cytokine Research 19(8): 911-921.

[83]. Uze G, Lutfalla G, Gresser I (1990) Genetic transfer of a functional human interferon alpha receptor into mouse cells, cloning and expression of its cDNA. Cell 60(2): 225-234.

[84]. Wong V.K, Cheong-Lee C, Ford J.A, Yoshida E.M ( 2005) Acute sensorineural hearing loss associated with peginterferon and ribavirin combination therapy during hepatitis $\mathrm{C}$ treatment, outcome after resumption of therapy. World J. of Gastroenterol 11(34): 5392-5393.

[85]. Woolf N.K, Harris J.P, Ryan A.F, Butler D.M, Richman D.D (1985) Hearing loss in experimental cytomegalovirus infection of the guinea pig inner ear: prevention by systemic immunity. Ann Otol Rhinol Laryngol 94(4 Pt 1): 350-6.

[86]. Yamane H, Iguchi H, Konishi K, Nakagawa T, Nakai Y, et al. (1995) Natural killer cell response in the inner ear. Acta Otolaryngol 115 (6): 738-41.

[87]. Yamanobe S, Harris J.P (1992) Spontaneous remission in experimental autoimmune labyrinthitis. Ann of Otolol Rhinol and Laryngol 101(12): 100714.

[88]. York J.D, Odom A.R, Murphy R, Ives E.B, Wente S.R (1999) A phospholipase C-dependent inositol polyphosphate kinase pathway required for efficient messenger RNA export. Science 285(5424): 96-100.

[89]. Yoshino S (1996) Effects of oral administration of type I interferon on adjuvant arthritis in rats. Comparative Immunology, Microbiology and Infectious Diseases 19(2): 133-138. 